7. Reprod. Fert. (1970) 23, 365-367

\title{
SEX PROPORTION OF DOMESTIC CHICKEN AT 16 HOURS OF INCUBATION
}

\author{
N. S. FECHHEIMER, J. R. LODGE* AND R. G. MILLER \\ Animal Reproduction Teaching and Research Center, Department of Dairy Science, \\ The Ohio State University, Columbus, Ohio 43210, U.S.A.
}

(Received 29th Fune 1970)

Summary. The sex of 918 chicken embryos after incubation for 16 to $18 \mathrm{hr}$ was ascertained by chromosomal analysis. The proportion of males was $49 \cdot 45 \% \pm 1 \cdot 6 \%$.

The sex ratio of a limited number of 16-hr chick embryos was reported by Fechheimer, Zartman \& Jaap (1968). Two additional experiments have now been completed in which it was possible to determine the sex of the embryos by chromosomal examination after the embryos had been incubated for $16 \mathrm{hr}$. This report contains the results from the three independent experiments in which the chromosomal sex of 918 embryos has been ascertained.

The previously published data dealt with observations of embryos of a broiler strain of chickens that has been used as a random-bred control line for selection experiments (Jaap, 1963). The present data were gathered from diverse genetic stocks. For one set, a broiler strain of chickens was again used. This line was derived from the random-bred control line and has been subjected to eight generations of intense selection for increased body weight at 8 weeks of age. The other line consisted of White Leghorn hens into which the dwarf $(d w)$ gene had been introduced. The males used as sires were from a standard, commercial, White Leghorn stock.

Eggs were collected daily from hens which had been inseminated artificially. Following storage at 10 to $12^{\circ} \mathrm{G}$ for a maximum of 7 days, they were placed in an incubator at $37.8^{\circ} \mathrm{C}$. After incubation for $16 \mathrm{hr}$, each egg was injected with $0.1 \mathrm{ml}$ of an aqueous solution containing $0.1 \mathrm{mg}$ Colcemid and returned to the incubator for 3 to $4 \mathrm{hr}$. In the laboratory, the content of each egg was emptied into a petri dish and the blastodisk was carefully removed on the tip of a scalpel. With a pipette, the embryo was removed from the scalpel in a drop of medium TG 199 and put in a 3-ml centrifuge tube containing about $1 \mathrm{ml}$ of medium. A cell suspension was prepared by aspirating the contents of the tube with the pipette. The tubes were centrifuged and the supernatant fluid was removed and replaced with a hypotonic solution composed of one part calf serum to three parts distilled water. After centrifuging, the hypotonic solution was replaced with acetic acid-methanol (1:3) fixative. Two changes of fixative were made, after which all but four to five drops of supernatant fixative was

* Permanent address: Department of Dairy Science, University of Illinois, Urbana 61801. 
removed and the cells were resuspended. Slide preparations were made by dropping the cell suspension onto cold, wet slides and drying them without the application of heat. Giemsa stain was applied. The sex of an embryo was determined by ascertaining the presence of one $\mathrm{Z}$ (female) or two $\mathrm{Z}$ (male) chromosomes in a minimum of five unbroken diploid cells in which all six pairs of macrochromosomes could be identified. In many of the better preparations with only one $\mathrm{Z}$ chromosome, the small metacentric $\mathrm{W}$ chromosome could be identified also.

It can be seen from Table 1 that the proportions of male embryos in the three experiments were $0.504,0.504$ and 0.477 . A test of heterogeneity (Woolf, 1957) was performed. Because it failed to yield evidence that the three samples were drawn from more than one population $(P<0.5)$, the data were pooled. The proportion of males in the total sample of 918 embryos was $0.4945 \pm 0.016$. This did not differ significantly from a proportion of $0.50\left(\chi^{2}=0.1089\right.$, $\mathrm{df}=1, P<0.70)$.

\section{TABLE 1}

NUMBERS OF MALE AND FEMALE EMBRYOS AND THE PROPORTION OF MALES AMONG GHICKEN EMBRYOS AFTER INGUBATION FOR 16 HR

\begin{tabular}{c|c|c|c|c|c}
\hline $\begin{array}{c}\text { Experiment } \\
\text { no. }\end{array}$ & Stock used & $\begin{array}{c}\text { No. of males } \\
(\mathcal{Z} \mid Z)\end{array}$ & $\begin{array}{c}\text { No. of females } \\
(Z / W)\end{array}$ & $\begin{array}{c}\text { Total no. of } \\
\text { embryos }\end{array}$ & $\begin{array}{c}\text { Mean } \% \\
\text { Males } \pm S . E .\end{array}$ \\
\hline 1 & Random-bred broiler & 122 & 120 & 242 & $50 \cdot 4 \pm 3 \cdot 2$ \\
2 & $\begin{array}{l}\text { Selected broiler } \\
3\end{array}$ & 159 & 174 & 333 & $47 \cdot 7 \pm 2 \cdot 7$ \\
\hline & Leghorn & 173 & 170 & 343 & $50 \cdot 4 \pm 2 \cdot 7$ \\
\hline
\end{tabular}

The chick embryo at $16 \mathrm{hr}$ of incubation is at mid-gastrulation. While the sex proportions found are not the primary ones, they probably differ little from those that would be found at the time of oviposition because there is a very low incidence of embryo death in the first $16 \mathrm{hr}$ of incubation. Furthermore, the three stocks used in our experiments differ markedly in their fertility and hatchability; the Leghorns used in Exp. 3 are highest in both respects followed by the random-bred broiler stock of Exp. 1. The growth selected line used in Exp. 2 is lowest in both respects. In the most favourable of circumstances, about $97 \%$ of ova were fertilized in our Leghorn stock and embryo death was less than $1 \%$. It is unlikely that the sex ratio of these lost embryos would be so divergent as to cause a significant alteration of the sex proportion in the total sample of eggs. This speculation is strengthened when one compares the Leghorn with the random-bred line from which the proportion of live embryos recovered at $16 \mathrm{hr}$ was only $62.8 \%$ of eggs laid (Fechheimer et al., 1968). In spite of the loss through infertility and early embryo death of $37.2 \%$ of the potential embryos, the sex ratio was found to be essentially the same as in the Leghorn stock. In view of these considerations, it is thought that the sex proportions observed were close approximations to the primary sex proportion.

Vickers (1969) reported that the sex proportion in 3- to 4-day mouse embryos was $50 \%$. The stage of development of mice at this time is even more 
primitive than that of chick embryos at $16 \mathrm{hr}$ of incubation so that it would appear that no material difference exists between these two species in the primary sex ratio. Differences in sex ratio that may appear during foetal, or perinatal, periods must therefore be attributable to differential viability of the embryos and foetuses of the two sexes.

This work was supported by a National Institutes of Health Special Fellowship to J.R.L. and by Grant HD 03822 from the same agency. We are indebted to Professor R. G. Jaap for technical advice and for provision of the eggs.

\section{REFERENCES}

Fechieimer, N. S., Zartman, D. L. \& JAAP, R. G. (1968) Estimates of the primary and subsequent embryonic sex ratios in the chicken. Proc. VI Cong. Int. Reprod. Anim. Insem. Artif. (Paris), 1, 417.

JAAP, R. G. (1963) Selection for rapid growth rate in chickens. Poult. Sci. 42, 1393.

Vickers, A. D. (1969) Delayed fertilization and the prenatal sex-ratio of the mouse. F. Reprod. Fert. 20, 63.

Woolf, B. (1957) The Log Likelihood Ratio Test (The G-Test). Ann. hum. Genet. 21, 397. 